DOI 10.31558/2518-7953.2019.1.4

УДК 346.9 (043.3)

B. І. Новошицька

доцент кафедри господарського права

Донецького національного університету

імені Василя Стуса,

канд. юрид. наук

\title{
ЩОДО ВАРТОСТІ ВТРАЧЕНОГО, ПОШКОДЖЕНОГО АБО ЗНИЩЕНОГО МАЙНА У СКЛАДІ ЗБИТКІВ У СФЕРІ ГОСПОДАРЮВАННЯ
}

Ключові слова: збитки у сфері господарювання, відикодування збитків, склад збитків, вартість втраченого майна, вартість пошкодженого майна, вартість знищеного майна.

Збитки у сфері господарювання, серед іншого, можуть бути завдані внаслідок втрати, пошкодження або знищення майна, вартість якого включається до складу збитків та підлягає відшкодуванню особою, яка їх завдала.

Основним нормативно-правовим актом, що регулює відносини зі стягнення зазначеної складової збитків у сфері господарювання $\epsilon$ Господарський кодекс України (далі - ГК України), однак окремі його положення в цій частині містять низку недоліків і потребують уточнення [1].

Практика вказує на те, що у багатьох випадках задоволення вимог про стягнення вартості втраченого, пошкодженого або знищеного майна у складі збитків виявляється неможливим через неоднозначність застосування норм законодавства про відшкодування цієї складової збитків та складність розрахунку суми таких збитків. Крім цього, при обгрунтуванні своїх позовних вимог суб'єкти господарювання часто розповсюджують на ці відносини норми Цивільного кодексу України (далі - ЦК України) [2] без врахування особливостей, які сьогодні встановлено для сфери господарювання.

Окремі аспекти відшкодування вартості втраченого, пошкодженого або знищеного майна у складі збитків висвітлювали у своїх дослідженнях представники різних галузей юридичної науки, зокрема, в останні роки, такі автори як Т. Є. Крисань, I. В. Подколзін, І. В. Розізнана, 3. Ф. Татькова, А. В. Янчук та ін., проте в їх роботах зазначені аспекти розглядалися або опосередковано або без урахування особливостей такого відшкодування саме у сфері господарювання.

Наведене вказує на актуальність та доцільність наукового дослідження порушеного питання. 
Метою дослідження є обтрунтування пропозииій щзодо визначення вартості втраченого, пошкодженого або знищеного майна у складі збитків у сфері господарювання.

Збитки у сфері господарювання за своєю природою є неоднорідними та можуть складатися з декількох частин. Відповідно до абз. 2 ч. 1 ст. 225 ГК України до складу збитків, що підлягають відшкодуванню особою, яка допустила господарське правопорушення, серед іншого, включається вартість втраченого, пошкодженого або знищеного майна, визначена відповідно до вимог законодавства.

Характеризуючи зазначену складову збитків, перш за все необхідно звернути увагу, що в ГК України мова йде про майно, на відміну від ЦК України, де мова йде про речі (п. 1 ч. 2 ст. 22). При цьому, під майном розуміється сукупність речей та інших цінностей (включаючи нематеріальні активи), які мають вартісне визначення, виробляються чи використовуються у діяльності суб'єктів господарювання та відображаються в їх балансі або враховуються в інших передбачених законом формах обліку майна цих суб’єктів (ч. 1 ст. 139 ГК України). ЦК України також надає визначення поняттю «майно», під яким розуміється окрема річ, сукупність речей, а також майнові права та обов'язки (ч. 1 ст. 190). В той же час річчю $є$ предмет матеріального світу, щодо якого можуть виникати цивільні права та обов'язки (ч. 1 ст. 179 ЦК України). Отже, поняття майна $\epsilon$ ширшим.

3 цього приводу Т. Є. Крисань зазначає, що у літературі $є$ точка зору, згідно 3 якою законодавець, визначаючи у п. 1 ч. 2 ст. 22 ЦК України досліджувану складову збитків як втрати, яких особа зазнала у зв'язку зі знищенням або пошкодженням речі, мав на увазі майно у вузькому значенні, тобто мав на увазі під майном матеріальні цінності, а не права кредитора, оскільки права кредитора не можуть бути об'єктом пошкодження або втрати. В даний час в обігу беруть активну участь не тільки речі, але і права вимоги, а також інформація, які, інколи, представляють більшу цінність, ніж самі предмети матеріального світу - речі. Проте в сучасному світі права вимоги так міцно увійшли до цивільного обігу, набули такої високої вартості, що стали витісняти речі. Оскільки значення існування права в цілому обертається навколо майна, яке представляє цінність для конкретних осіб і для обігу в цілому, остільки і збитки можуть бути заподіяні будь-якому такому майну. Тому, на її думку, не можна зводити розуміння поняття «майно» в ч. 2 ст. 190 ЦК України виключно до речей [3, с. 7].

Таким чином, важливою особливістю досліджуваної складової збитків у сфеpi господарювання $\epsilon$ те, що стосується вона саме вартості майна господарськовиробничого призначення, у тому значенні, яке воно має у цій сфері.

Заслуговує уваги і те, що до складу вказаних збитків входить саме вартість втраченого, пошкодженого або знищеного майна (абз. 2 ч. 1 ст. 225 ГК України), 
а не втрати, яких особа зазнала у зв'язку зі знищенням або пошкодженням речі (п. 1 ч. 2 ст. 22 ЦК України). При цьому визначення вартості може бути взято як еквівалент цінності об'єкта оцінки, виражений у ймовірній сумі грошей, тобто найбільша сума грошей, яку може отримати продавець та може погодитися сплатити покупець (п. 3 Національного стандарту № 1 «Загальні засади оцінки майна і майнових прав», затвердженого постановою Кабінету Міністрів України від 10 вересня 2003 р. № 1440) [4].

Така вартість може бути поточною, під якою розуміється вартість, приведена у відповідність з цінами на дату оцінки шляхом дисконтування або використання фактичних цін на дату оцінки, чи ринковою, тобто вартістю, за якою можливе відчуження об'єкта оцінки на ринку подібного майна на дату оцінки за угодою, укладеною між покупцем та продавцем, після проведення відповідного маркетингу за умови, що кожна із сторін діяла із знанням справи, розсудливо $\mathrm{i}$ без примусу (п. 3 вищеназваного Національного стандарту).

Для розуміння сутності терміну «втрачене майно» можна взяти за основу визначення втрати речі (майна), під якою розуміють вибуття з володіння кредитора речі (майна), яка є його власністю або знаходиться у нього на основі іншого титульного володіння. При цьому не має значення сам спосіб втрати (загублення, залишення без нагляду, не витребування тощо), а також вид майна, яке втрачене (річ, гроші, інші матеріальні цінності). Важливо, щоб внаслідок такої втрати майнова сфера кредитора зазнала зменшення [5, с. 79].

При вирішенні питання про стягнення збитків у вигляді вартості втраченого майна можна звернутися до Роз'яснення Вищого арбітражного суду України «Про деякі питання практики вирішення спорів, пов'язаних 3 відшкодуванням шкоди» від 1 квітня 1994 р. № 02-5/215, в якому щодо відшкодування вартості втраченої речі зазначається, що позовні вимоги підлягають задоволенню в розмірі дійсної іiі вартості на момент розгляду справи (п. 7). Однак це не виключає права потерпілої особи крім вартості речі вимагати стягнення збитків, заподіяних у зв'язку із втратою речі [6].

Доволі близьким за змістом, але не тотожним до поняття «втраченого майна» $є$ поняття «знищеного майна», яке також вказує на фактичне вибуття речі (майна) із володіння особи, власника чи титульного володільця. Однак відмінність між цими поняттями полягає у тому, що внаслідок знищення майна останнє перестає існувати і його відновлення можливе лише через придбання аналогічного майна (у разі, коли знищена річ, визначена родовими ознаками) або шляхом відшкодування іiі вартості (у випадку знищення речей, визначених індивідуальними ознаками). Натомість у випадку втрати майна його фізична загибель (фізичне знищення) не завжди має місце, адже втрата - це і загублення, і втрата через викрадення [5, с. 80]. 
I. В. Подколзін зазначає, що під знищенням майна необхідно розуміти повну загибель майна внаслідок дій сторін чи інших осіб, а також різних подій чи явищ. При цьому зменшення майнового активу потерпілої особи може відбутися i без його загибелі, наприклад, у зв'язку з його викраденням чи загубленням, що охоплюється поняттям «втрата майна», але не враховано в ЦК України. Власне цей висновок підтверджувався ст. 203 ЦК УРСР, в якій збитками визнавалася втрата майна. У широкому розумінні під втратою майна можна розуміти різні способи його ліквідації, у тому числі шляхом його загублення, знищення. Крім цього, I. В. Подколзін звертає увагу, що в ст. 224 ГК України не передбачено знищення майна, яке призводить до виникнення збитків. Натомість вже в ст. 225 ГК України, яка має назву «Склад та розмір відшкодування збитків», прямо зазначається, що вартість втраченого, пошкодженого або знищеного майна включається до складу збитків, які підлягають відшкодуванню. Отже, наявною є також суперечність між ст. 224 і ст. 225 ГК України [7, с. 15].

3 огляду на зазначене, доиільно визначити у ст. 224 ГК України, що збитки у сфері господарювання можуть бути наслідком також $і$ знищення майна. Це випливає з положень ч. $1 \mathrm{~cm} .225$ ГК Украӥни, де перелічено склад збитків, адже поняття «втрата» та «знищення» є різними за своїм змістом.

Ще однією частиною цієї складової збитків у сфері господарювання $\epsilon$ вартість пошкодженого майна. 3 приводу визначення поняття «пошкодження майна» Т. Є. Крисань відзначає, що за змістом ЦК України це поняття охоплює всі несприятливі зміни як тимчасового характеру, які вимагають витрат по їх усуненню, так і необігові, які допускають використання речей за тим або іншим призначенням із зниженням їх вартості (часткове пошкодження), а іноді приводять до втрати цінності майна повністю і до абсолютної неможливості його використання, тобто загибелі (повне пошкодження). Пошкодження майна виражається у втраті майном його корисних властивостей $[3$, с. 6].

Постанова Пленуму Верховного Суду України «Про судову практику в справах про знищення та пошкодження державного чи колективного майна шляхом підпалу або внаслідок порушення встановлених законодавством вимог пожежної безпеки» від 2 липня 1976 р. № 4 визначає, що під пошкодженням речі слід розуміти погіршення якості, зменшення цінності речі або приведення ії на якийсь час у непридатний до використання за цільовим призначенням стан (п. 2) [8].

3 наведеного слідує, що внаслідок пошкодження майно або може підлягати відновленню, або його відновлення і подальше використання за цільовим призначенням $\epsilon$ неможливим. Очевидно, що стан майна після пошкодження повинен бути одним із критеріїв розрахунку розміру збитків, що підлягатимуть відшкодуванню.

3 цього приводу слід звернути увагу, що ГК України передбачає стягнення саме вартості пошкодженого майна, при цьому ступінь пошкодження не врахо- 
вується, а отже стягнення вартості майна передбачається і для тих випадків, коли майно може бути відновлено та використано за призначенням у діяльності суб'єкта господарювання. Однак таке формулювання може бути прийнятним тільки в тому випадку, якщо внаслідок пошкодження речі їі якість змінилася настільки, що вона не може бути використана за первісним призначенням, бо в інших випадках матиме місце отримання кредитором необгрунтованого доходу.

Зазначене питання викликає неоднозначне тлумачення і на практиці. Зокрема, становить інтерес рішення господарського суду м. Києва від 17 червня 2015 р. у справі № 910/11716/15, у якому пояснюється, що саме слід мати на увазі під вартістю втраченого, знищеного або пошкодженого майна та чи є придбання нової речі замість втраченої підставою для стягнення збитків. При цьому обгрунтовується, що вартість пошкодженого майна (ч. 1 ст. 225 ГК України) слід тлумачити як грошову суму, на яку зменшилась вартість такого майна [9]. Представляє інтерес і рішення господарського суду м. Києва від 18 квітня 2018 р. у справі № 910/21667/17, в якому суд з посиланням вже на ст. 1192 ЦК України зазначив, що наведеною нормою не передбачено обов'язку особи, яка має відповідати за завдану шкоду, відшкодовувати вартість саме нової речі, яка у даному випадку придбана позивачем, а тому суд дійшов висновку, що підстави для стягнення 3 відповідача на користь позивача 143 810,00 грн матеріальної шкоди, що є фактично частиною вартості придбання позивачем нової конструкції, - відсутні [10].

Підтвердження зазначеної позиції знаходить своє відображення і в нормах спеціального законодавства. Так, згідно зі ст. 29 Закону України «Про обов’язкове страхування цивільно-правової відповідальності власників наземних транспортних засобів» у зв'язку з пошкодженням транспортного засобу відшкодовуються витрати, пов'язані з відновлювальним ремонтом транспортного засобу з урахуванням зносу, розрахованого у порядку, встановленому законодавством [11].

При вирішенні питання про стягнення збитків у вигляді вартості пошкодженого майна можна звернутися до Роз'яснення Вищого арбітражного суду України «Про деякі питання практики вирішення спорів, пов'язаних 3 відшкодуванням шкоди» від 1 квітня 1994 р. № 02-5/215, де зазначено, що витрати потерпілої особи з виправлення пошкодженого майна іiі засобами і коштами визначаються, виходячи з реальних витрат позивача (п. 7).

Щодо сфери господарювання Тимчасова методика визначення розміру шкоди (збитків), заподіяної порушенням господарських договорів вирішує зазначене питання шляхом встановлення правила, за яким при пошкодженні майна визначається сума уцінки або витрати з усунення пошкодження (п. 3). Збитки такого роду можуть бути нанесені, наприклад, в результаті порушення умов договору щодо тари та упаковки, несправності поставленого обладнання та з інших причин [12]. 
Разом 3 тим таке вирішення питання також потребує доопрацювання, адже не враховує випадки, коли пошкоджене майно не може бути відновлено.

Для вирішення зазначеного питання доцільно звернутися до ст. 951 ЦК України, положення якої може бути взято за основу при доопрацюванні питання щодо стягнення збитків від пошкодження майна. Згідно з цією статтею збитки, завдані поклажодавцеві пошкодженням речі, відшкодовуються зберігачем у розмірі суми, на яку знизилася іiї вартість. При цьому, якщо внаслідок пошкодження речі 110 якість змінилася настільки, що вона не може бути використана за первісним призначенням, поклажодавець має право відмовитися від цієї речі і вимагати від зберігача відшкодування iї вартості.

Наведене стосується конкретних відносин, але може бути використано для уточнення такої складової збитків у сфері господарювання як вартість пошкодженого майна. При цьому включення до складу збитків вартості пошкодженого майна може бути прийнятним тільки в тому випадку, якщо внаслідок пошкодження майна його якість змінилася настільки, що воно не може бути використаним за первісним призначенням. У всіх же інших випадках мова повинна йти про відшкодування вартості витрат на усунення таких пошкоджень, адже стягнення вартості пошкодженого майна за можливості його відновлення приводитиме до отримання кредитором необгрунтованого доходу.

3 урахуванням цьвого, доцільно викласти абзаи 2 частини 1 статті 225 ГК Украйни у такій редакиї: «вартість втраченого, пошкодженого (яке не може бути використано за первісним призначенням) або знищеного майна, визначена відповідно до вимог законодавства; вартість витрат на усунення пошкоджень, якщо майно підлягає відновленню».

Внесення зазначених змін та врахування суб'єктами господарювання викладених пропозицій сприятиме застосуванню господарськими судами однакових правових позицій та надасть можливість суб'єктам господарювання, права яких порушено, стягнути збитки у повному обсязі, в той же час, не приводитиме до їх необгрунтованого збагачення.

1. Господарський кодекс України: Закон України від 16 січня 2003 р. № 436-IV. Відомості Верховної Ради Украӥни. 2003. № 18. Ст. 144. (Із змінами).

2. Цивільний кодекс України: Закон України від 16 січня 2003 р. № 435-IV. Вiдомості Верховної Ради Украӥни. 2003. № 40. Ст. 356. (Із змінами).

3. Крисань Т. С. Збитки як категорія цивільного права України: автореф. дис. ... канд. юрид. наук: 12.00 .03 «Цивільне право і цивільний процес; сімейне право; міжнародне приватне право». Одеська нац. юрид. академія. Одеса, 2008. 19 с.

4. Про затвердження Національного стандарту № 1 «Загальні засади оцінки майна і майнових прав»: Постанова Кабінету Міністрів України від 10 вересня 2003 р. № 1440. Офіиійний вісник Украӥни. 2003. № 37. Ст. 1995. 
5. Розізнана I. В. Поняття та зміст збитків при порушенні договірних зобов'язань. Науковий вісник Ужсгородського національного університету. 2014. № 26. С. 78-81.

6. Про деякі питання практики вирішення спорів, пов'язаних з відшкодуванням шкоди: Роз'яснення Вищого арбітражного суду України від 1 квітня 1994 р. № 02-5/215. Офічійний веб-портал Верховної Ради Украӥни. URL: http://zakon3.rada.gov.ua/laws/show/v_215800-94 (дата звернення 16.05.2019).

7. Подколзін I. В. Збитки та їх відшкодування в договірному праві України: автореф. дис. ... канд. юрид. наук: 12.00 .03 «Цивільне право і цивільний процес; сімейне право; міжнародне приватне право». Київський нац. університет імені Тараса Шевченка. Київ, 2009. 22 с.

8. Про судову практику в справах про знищення та пошкодження державного чи колективного майна шляхом підпалу або внаслідок порушення встановлених законодавством вимог пожежної безпеки: Постанова Пленуму Верховного Суду України від 2 липня 1976 р. № 4. Офіиійний веб-портал Верховної Ради Украӥни. URL: http://zakon3.rada.gov.ua/laws/show/ v0004700-76 (дата звернення 16.05.2019).

9. Рішення господарського суду м. Києва від 17 червня 2015 р. у справі № 910/11716/15. Єдиний державний реєстр судових рімень. URL: http://www.reyestr.court.gov.ua/Review/45903246 (дата звернення 16.05.2019).

10. Рішення господарського суду м. Києва від 18 квітня 2018 р. у справі № 910/21667/17. Єдиний державний реєстр судових рімень. URL: http://www.reyestr.court.gov.ua/Review/73629733 (дата звернення 16.05.2019).

11. Про обов'язкове страхування цивільно-правової відповідальності власників наземних транспортних засобів: Закон України від 1 липня 2004 р. № 1961-IV. Офіційний вісник України. 2004. № 30. Ст. 2000.

12. Временная Методика определения размера ущерба (убытков), причиненного нарушениями хозяйственных договоров: одобрена Государственной комиссией Совета Министров СССР по экономической реформе 21 декабря 1990 г. Офіиійний веб-портал Верховної Ради України. URL: http://zakon4.rada.gov.ua/laws/show/n0001400-90 (дата звернення 16.05.2019). 